\title{
PENGARUH TINGKAT PERTUMBUHAN, STRUKTUR AKTIVA, PROFITABILITAS, DAN LIKUIDITAS TERHADAP STRUKTUR MODAL PERUSAHAAN PERTAMBANGAN DI BEI
}

\author{
Made Yunitri Deviani ${ }^{1}$ \\ Luh Komang Sudjarni² \\ ${ }^{1,2}$ Fakultas Ekonomi dan Bisnis Universitas Udayana, Bali, Indonesia \\ Email: yunitrideviani@gmail.com
}

\begin{abstract}
ABSTRAK
Persaingan dalam dunia bisnis mendorong manajer keuangan untuk mengambil keputusan dengan cermat, salah satunya keputusan terkait struktur modal. Penelitian ini bertujuan untuk menguji pengaruh tingkat pertumbuhan, struktur aktiva, profitabilitas, dan likuiditas terhadap struktur modal perusahaan pertambangan di Bursa Efek Indonesia periode 2012-2015. Penelitian ini menggunakan desain asosiatif dengan pendekatan kuantitatif. Struktur modal dihitung dengan long term debt to equity ratio, struktur aktiva dengan membandingkan aktiva lancar dengan aktiva tetap, profitabilitas dihitung dengan return on equity, serta likuiditas dihitung dengan current ratio. Metode yang digunakan untuk menentukan sampel yaitu metode purposive sampling dengan ukuran sampel 23 perusahaan. Teknik analisis data yang digunakan adalah analisis regresi linear berganda. Hasil dalam penelitian ini menunjukkan bahwa, secara parsial tingkat pertumbuhan memiliki pengaruh negatif dan signifikan terhadap struktur modal, struktur aktiva memiliki pengaruh negatif namun tidak signifikan terhadap struktur modal, serta profitabilitas dan likuiditas memiliki pengaruh negatif dan signifikn terhdap struktur modal.
\end{abstract}

Kata kunci : tingkat pertumbuhan, struktur aktiva, profitabilitas, likuiditas, struktur modal

\begin{abstract}
Competition in the business world encourages financial managers to take decisions carefully, one of which decisions related to capital structure. This study aims to examine the effect of growth rate, asset structure, profitability, and liquidity on the capital structure of mining companies in Indonesia Stock Exchange period 2012-2015 period. This research uses associative design with quantitative approach. Capital structure is calculated by long term debt to equity ratio, asset structure by comparing current assets with fixed assets, profitability is calculated by return on equity, and liquidity is calculated by current ratio. The method used to determine the sample is purposive sampling method with sample size 23 companies. Data analysis technique used is multiple linear regression analysis. The results showed that partially significant growth rate negatively affect the capital structure, asset structure has a negative but not significant effect on capital structure, and profitability and liquidity have a significant negative effect on capital structure.
\end{abstract}

Keyword: growth, asset structure, profitability, liquidity, capital structure 


\section{PENDAHULUAN}

Era globalisasi telah membawa persaingan yang ketat dalam dunia bisnis. Agar mampu menghadapi persaingan global, perusahaan dihadapkan dengan pengambilan keputusan keuangan, yaitu keputusan pendanaan dan keputusan investasi. Keputusan pendanaan sangat penting bagi perusahaan dalam menghadapi persaingan. Perusahaan dituntut mampu menjaga ketersediaan dana dalam perusahaan, untuk menunjang kegiatan operasional perusahaan dalam rangka melakukan pengembangan perusahaan, melakukan investasi, dan untuk melakukan kegiatan lainnya. Struktur modal merupakan aspek yang penting dalam keputusan pendanaan. Pendanaan atau struktur modal dari perusahaan apabila tidak dikelola dengan optimal, maka dapat menimbulkan dampak kesulitan keuangan bagi perusahaan.

Struktur modal merupakan pembelanjaan permanen dari perusahaan yang mencerminkan perbandingan atau perimbangan antara hutang jangka panjang perusahaan dengan modal sendiri perusahaan yang berupa laba ditahan dan penerbitan saham. Modal perusahaan dapat bersumber dari internal perusahaan maupun eksternal perusahaan. Pendanaan yang bersumber dari internal perusahaan berasal dari laba ditahan dan akumulasi penyusutan. Pendanaan eksternal berasal dari penggunaan hutang atau penerbitan saham.

Penggunaan hutang oleh perusahaan akan menimbulkan biaya bunga dan sangat berisiko saat keadaan ekonomi sedang tidak stabil. Di sisi lain, adanya biaya bunga akan mampu mengurangi pajak yang ditanggung oleh perusahaan. Penggunaan dana internal berupa laba ditahan terbilang sangat baik namun, apabila 
laba ditahan yang dimiliki oleh perusahaan terbilang kecil, maka perusahaan juga tidak dapat hanya menggunakan laba ditahan saja, melainkan harus menggunakan dana eksternal (Liem et al., 2013). Oleh karena itu, manajer suatu perusahaan terutama manajer keuangan, perlu menyusun struktur modal dengan cermat dan tepat agar tidak menimbulkan kerugian bahkan kebangkrutan bagi perusahaan.

Struktur modal suatu aspek yang sangat penting yang perlu diperhatikan oleh perusahaan karena keputusan mengenai struktur modal dapat berpengaruh terhadap kondisi maupun penilaian kinerja keuangan perusahaan yang juga akan mempengaruhi nilai dari suatu perusahaan (Putri, 2012). Terdapat beberapa teori mengenai struktur modal, menurut Brigham dan Houston (2011:179-185) diantaranya Modigliani-Miller (MM) Theory, Trade- Off Theory atau Teori pertukaran, dan Signalling Theory (Teori Sinyal). Sedangkan menurut Husnan (2012:278) terdapat Pecking Order Theory yang juga merupakan teori yang mendasari struktur modal.

Teori struktur modal modern pertama yaitu teori Modigliani-Miller (MM) dikemukakan tahun 1958 yang mengembangkan teori struktur modal tanpa pajak dengan kondisi pasar sempurna. Teori Modigliani-Miller (MM) tersebut, dinyatakan bahwa struktur modal tidak memiliki pengaruh terhadap nilai dari suatu perusahaan. Sebagian dari asumsi-asumsi yang dikemukakan dalam teori tersebut dianggap kurang realistis. Tahun 1963, teori MM diperbaharui yaitu dengan efek pajak sehingga struktur modal memiliki hubungan dengan nilai perusahaan. TradeOff Theory atau teori pertukaran merupakan teori struktur modal dimana terdapat asumsi bahwa manfaat berupa pengehematan pajak dari penggunaan hutang akan 
ditukarkan dengan masalah yang ditimbulkan oleh penggunaan hutang yang menyebabkan adanya potensi terjadinya kebangkrutan (Brigham dan Houston, 2011:183). Trade-Off Theory ini menyatakan struktur modal yang optimal akan memaksimalkan harga saham (Brigham dan Houston, 2011:184).

Signalling Theory menyatakan asumsi adanya informasi asimetri (asymetric information) antara investor dengan manajer perusahaan. Berdasakan teori sinyal ini, perusahaan menunjukkan sikap optimis dengan menggunakan hutang yang lebih banyak yang menunjukkan bahwa di masa yang akan datang prospek perusahaan akan cerah. Pecking Order Theory menyatakan bahwa perusahaan cenderung akan menggunakan pendanaan internal yang dari laba perusahaan yang berupa laba ditahan apabila perusahaan memiliki profitabilitas yang tinggi. Berdasarkan teori ini, terdapat hierarki penggunaan sumber dana yaitu penggunaan dana internal terlebih dahulu, kemudian jika dana internal tidak memadai, pendanaan perusahaan akan berasal dari penggunaan hutang dan pilihan yang terakhir yaitu penerbitan saham (Husnan, 2012:278).

Struktur modal perusahaan dipengaruhi oleh beberpa faktor. Brigham dan Houston (2011:188) menyatakan bahwa terdapat beberapa faktor yang mempengaruhi struktur modal diantaranya, stabilitas penjualan, struktur aset, leverage operasi, tingkat pertumbuhan, profitabilitas, pajak, kendali, sikap manajemen, sikap pemberi pinjaman dan lembaga pemeringkat, kondisi pasar, kondisi internal perusahaan, dan fleksibilitas keuangan. Riyanto (2010:248) mengungkapkan bahwa dalam menentukan struktur modal terdapat beberapa faktor atau hal yang perlu dipertimbangkan dan diperhatikan yaitu tingkat penjualan, 
struktur aktiva, tingkat pertumbuhan perusahaan, profitabilitas, variabel laba dan perlindungan pajak, skala perusahaan, kondisi intern perusahaan dan ekonomi makro. Alipour et al. (2015) menyatakan bahwa faktor-faktor yag mempengaruhi struktur modal diantaranya, ukuran dari perusahaan, fleksibilitas keuangan, struktur aktiva, profitabilitas, likuiditas dan pertumbuhan. Variabel yang digunakan yaitu dalam penelitian ini yaitu, tingkat pertumbuhan, struktur aktiva, profitabilitas, dan likuiditas, dimana keempat variabel tersebut merupakan variabel yang mempengaruhi struktur modal.

Variabel pertama dalam penelitian ini yaitu tingkat pertumbuhan yang menunjukkan pertumbuhan suatu perusahaan untuk mengembangkan perusahaannya di masa mendatang. Tingkat pertumbuhan perusahaan yang semakin tinggi akan berdampak pada struktur modal perusahaan, dimana perusahaan akan cenderung untuk menahan penggunaan hutang untuk menghindari risiko akibat ketidakpastian bisnis (Brigham dan Houston, 2011:189). Tingkat pertumbuhan perusahaan dapat dicerminkan melalui pertumbuhan penjualan perusahaan. Suatu perusahaan yang memiliki tingkat pertumbuhan yang tinggi menunjukkan bahwa perusahaan tersebut memiliki dana internal yang lebih banyak. Pernyataan tersebut sesuai dengan pecking order theory, dimana perusahaan akan menggunakan dana internal berupa laba ditahan sebelum memutuskan untuk menggunakan pendanaan eksternal. Berdasarkan hal tersebut, apabila tingkat pertumbuhan suatu perusahaan meningkat, maka struktur modal dari suatu perusahaan akan menurun atau dengan kata lain, tingkat pertumbuhan akan berpengaruh negatif terhadap struktur modal suatu perusahaan. 
Penelitian sebelumnya mengenai pengaruh tingkat pertumbuhan, menunjukkan hasil yang berbeda atau tidak konsisten. Hasil penelitian yang dilakukan oleh Khairin dan Harto (2014), dan Yadav (2014) menunjukkan bahwa tingkat pertumbuhan berpengaruh positif signifikan terhadap struktur modal. Terdapat hasil yang berbeda dikemukakan oleh Alipour et al. (2015), Setyawan et al. (2016), serta Dewi dan Dana (2017) yang menemukan bahwa tingkat pertumbuhan memiliki pengaruh negatif dan signifikan terhadap struktur modal.

Variabel kedua dalam penelitian ini yaitu struktur aktiva yang menunjukkan perimbangan atau perbandingan aktiva lancar dengan aktiva tetap (Riyanto, 2011:22). Aktiva tetap yang dimiliki oleh perusahaan akan digunakan untuk menjalankan kegiatan operasional perusahaan. Riyanto (2011:298) menyatakan jika sebagian besar modal yang dimiliki oleh perusahaan tertanam dalam aktiva tetap maka perusahaan tersebut akan mengutamakan penggunaan modal sendiri, serta modal eksternal bersifat sebagai pelengkap. Perusahaan dengan jumlah aktiva lancar yang lebih besar akan mengutamakan penggunaan hutang jangka pendek. Jadi, semakin tinggi struktur aktiva yang merupakan perbandingan aktiva lancar dengan aktiva tetap, maka struktur modal perusahaan juga akan semakin tinggi.

Liestyasih dan Yadnya (2015) mengemukakan struktur aktiva memiliki pengaruh negatif signifikan terhadap struktur modal. Hasil penelitian tersebut juga didukung dengan hasil penelitian lainnya yang dilakukan oleh Sheikh dan Wang (2011), Alipour et al. (2015), dan Khairin dan Harto (2014) yang mengemukakan hasil penelitian bahwa struktur aktiva memiliki pengaruh negatif dan signifikan terhadap struktur modal perusahaan. Beberapa penelitian lainnya menunjukkan 
Made Yunitri Deviani, Pengaruh Tingkat Pertumbuhan, Struktur Aktiva...

hasil yang tidak konsisten atau berbeda. Seperti yang dikemukakan oleh Suweta dan Dewi (2016), Pattweekongka dan Napompech (2014) serta Liem et al. (2013) yang menemukan bahwa struktur aktiva memiliki pengaruh positif dan signifikan terhadap struktur modal.

Variabel ketiga dalam penelitian ini yaitu profitabilitas yang merupakan kemampuan perusahaan dalam mencapai keuntungan serta menjadi ukuran tingkat efektivitas manajemen perusahaan, yang ditunjukkan oleh laba yang dihasilkan oleh perusahaan dari hasil penjualan dan pendapatan investasi (Kasmir, 2011:196). Brigham dan Houston (2011:189) menyatakan perusahaan dengan tingkat profitabilitas yang tinggi ternyata menggunakan pendanaan berupa hutang dalam jumlah yang relatif rendah. Berdasarkan pecking order theory, perusahaan yang memiliki tingkat profitabilitas yang tinggi cenderung untuk memanfaatkan sumber dana internal berupa laba ditahan terlebih dahulu dan menggunakan pendanaan eksternal yang relatif rendah. Semakin tinggi tingkat profitabilitas perusahaan maka tingkat struktur modal perusahaan akan semakin rendah, karena pendanaan yang bersumber dari internal perusahaan memiliki risiko yang lebih rendah.

Terdapat beberapa penelitian yang mengenai pengaruh profitabilitas perusahaan terhadap struktur modal. Hasil penelitian dari Khairin dan Harto (2014) menyatakan bahwa profitabilitas berpengaruh positif signifikan terhadap struktur modal. Hasil penelitian ini didukung dengan hasil penelitian yang dilakukan oleh Setyawan et al. (2016), serta penelitian lainnya yang dilakukan oleh Hadianto dan Tayana (2010) menunjukkan bahwa profitabilitas berpengaruh memiliki pengaruh positif dan signifikan terhadap struktur modal. Terdapat perbedaan hasil penelitian 
pada beberapa penelitian lainnya. Pattweekongka dan Napompech (2014), Juliantika dan Dewi (2016), serta Ananto (2015) menemukan hasil bahwa profitabilitas memiliki pengaruh negatif dan signifikan terhadap struktur modal perusahaan.

Variabel keempat pada penelitian ini yaitu likuiditas yang merupakan kemampuan perusahaan untuk memenuhi kewajiban finansial yang bersifat jangka pendek dengan tepat waktu, yang ditunjukkan oleh besar kecilnya aktiva lancar yaitu aktiva yang mudah untuk diubah menjadi kas yang meliputi kas, surat berharga, piutang usaha dan persediaan (Sartono, 2014:116). Berdasarkan pecking order theory, suatu perusahaan yang memiliki tingkat likuiditas yang tinggi akan cenderung mengurangi penggunaan hutang. Semakin tinggi tingkat likuiditas suatu perusahaan maka struktur modal perusahaan akan menjadi semakin rendah. Likuiditas perusahaan yang tinggi menunjukkan bahwa perusahaan tersebut memiliki keuangan internal yang memadai untuk memenuhi kewajiban yang bersifat jangka pendeknya yang berdampak pada struktur modal.

Penelitian dari Sheikh dan Wang (2011) menunjukkan hasil bahwa likuiditas memiliki pengaruh negatif signifikan terhadap struktur modal perusahaan. Hasil penelitian yang sama pula dengan hasil penelitian dari Pattweekongka dan Napompech (2014), Ananto (2015) serta Juliantika dan Dewi (2016) yang menunjukkan bahwa likuiditas memiliki pengaruh negatif dan signifikan terhadap struktur modal. Hasil lainnya yang dikemukakan dalam penelitian yang dilakukan oleh Bhawa dan Dewi (2015) serta Kartika dan Dana (2015) yang menyatakan bahwa likuiditas memiliki pengaruh positif dan signifikan terhadap struktur modal. 
Made Yunitri Deviani, Pengaruh Tingkat Pertumbuhan, Struktur Aktiva...

Pertambangan merupakan sektor yang sensitif terhadap perekonomian dunia. Di Indonesia, sektor pertambangan termasuk sektor yang sangat berpengaruh terhadap perekonomian Indonesia. Ekspor Indonesia pada sektor pertambangan baik migas maupun nonmigas dari tahun 2012 sampai tahun 2015 mengalami penurunan secara berturut-turut (Kemenperin, 2017). Tahun 2013, ekspor pertambangan mengalami penurunan sebesar 7,25\% dari tahun 2012. Penurunan ekspor juga terjadi pada tahun 2014 dan 2015 yaitu sebesar 16,72\% dan 26,94\%. Penurunan ekspor tersebut disebabkan oleh berkurangnya permintaan impor batubara dan mineral dari global terhadap Indonesia.

Sektor pertambangan tidak hanya mengalami penurunan dalam hal ekspor saja. Indeks harga saham sektoral pertambangan juga mengalami penurunan berturut-turut dari tahun 2011 sampai tahun 2015 (Bursa Efek Indonesia, 2017). Penurunan indeks harga saham sektoral pertambangan ini menunjukkan minat investor untuk berinvestasi pada sektor pertambangan mengalami penurunan. Saham merupakan salah satu sumber pendanaan bagi perusahaan. Undang-Undang No. 4 Tahun 2009, menyatakan bahwa pemerintah Indonesia menghimbau agar perusahaan tambang di Indonesia membangun pabrik pengolahan dan pemurnian hasil penambangan atau yang disebut dengan smelter. Pembangunan smelter tentu membutuhkan pendanaan yang besar, baik dalam hal penambahan investasi dalam aktiva tetap maupun untuk kegiatan operasional yang akan berdampak pada struktur modal perusahaan. Berikut ini disajikan data long term debt to equity ratio dari perusahaan pertambangan yang terdaftar di Bursa Efek Indonesia periode 2012 sampai 2015 pada Tabel 1. 


\section{Tabel 1}

Perkembangan Long Term Debt to Equity Ratio (LTDER) Perusahaan Pertambangan di BEI Tahun 2012-2015 (Dalam Persentase)

\begin{tabular}{|c|c|c|c|c|}
\hline \multirow[t]{2}{*}{ NAMA PERUSAHAAN } & \multicolumn{4}{|c|}{$\begin{array}{c}\text { Long Term Debt to Equity Ratio } \\
\text { (LTDER) } \\
\text { (dalam persentase) }\end{array}$} \\
\hline & 2011 & 2012 & 2013 & 2014 \\
\hline PT Adaro Energy Tbk. & 93,42 & 86,54 & 73,08 & 64,15 \\
\hline PT Aneka Tambang Tbk. & 29,88 & 40,77 & 52,41 & 42,04 \\
\hline PT Atlas Resources Tbk. & 2,70 & 9,70 & 78,43 & 90,19 \\
\hline PT Ratu Prabu Energi Tbk. & 43,58 & 56,09 & 58,98 & 35,96 \\
\hline PT Bara Jaya Internasional Tbk. & 8,12 & 32,83 & 34,52 & 57,63 \\
\hline PT Benakat Integra Tbk. & 20,29 & 126,18 & 117,24 & 94,03 \\
\hline PT Baramulti Suksessarana Tbk. & 11,84 & 5,68 & 20,96 & 12,84 \\
\hline PT Bayan Resources Tbk. & 113,60 & 152,39 & 151,58 & 358,01 \\
\hline PT Cita Mineral Investindo Tbk. & 7,07 & 25,77 & 24,46 & 43,55 \\
\hline PT Citatah Tbk. & 34,03 & 41,55 & 41,35 & 50,70 \\
\hline PT Darma Henwa Tbk. & 15,00 & 14,89 & 8,46 & 18,10 \\
\hline PT Surya Esa Perkasa Tbk. & 32,60 & 16,16 & 23,47 & 28,91 \\
\hline PT Golden Energy Mines Tbk. & 1,12 & 1,27 & 1,43 & 21,05 \\
\hline PT Harum Energy Tbk. & 0,66 & 0,81 & 0,99 & 1,34 \\
\hline PT Vale Indonesia Tbk. & 25,91 & 23,21 & 19,07 & 16,72 \\
\hline PT Indo Tambangraya Megah Tbk. & 5,17 & 5,56 & 4,96 & 7,12 \\
\hline PT Resource Alam Indonesia Tbk. & 7,69 & 6,48 & 5,28 & 5,71 \\
\hline PT Medco Energi Internasional Tbk. & 163,71 & 136,59 & 142,82 & 239,68 \\
\hline PT Mitra Investindo Tbk. & 24,12 & 18,11 & 11,31 & 18,69 \\
\hline PT Tambang Batubara Bukit Asam Tbk. & 28,84 & 24,69 & 29,61 & 28,90 \\
\hline PT Petrosea Tbk. & 115,61 & 96,35 & 86,81 & 87,59 \\
\hline PT Timah Tbk. & 12,79 & 13,55 & 11,26 & 16,94 \\
\hline PT Toba Bara Tbk. & 9,05 & 27,37 & 47,50 & 37,58 \\
\hline
\end{tabular}

Sumber:www.idx.co.id (data diolah, 2017)

Berdasarkan Tabel 1 mengenai long term debt to equity ratio perusahaan pertambangan di BEI periode 2012-2015 mencerminkan adanya fluktuasi struktur modal perusahaan. Selain terdapat fluktuasi, beberapa perusahaan memiliki struktur modal yang tinggi yang lebih dari 100 persen. Struktur modal yang dihitung dengan long term debt to equity ratio, yang melebihi 100 persen menunjukkan bahwa perusahaan pertambangan tersebut mengunakan hutang yang lebih banyak lebih banyak daripada modal sendiri. Meskipun dengan penggunaan hutang, perusahaan 
Made Yunitri Deviani, Pengaruh Tingkat Pertumbuhan, Struktur Aktiva...

dapat melakukan penghematan pajak, namun penggunaan hutang yang tinggi dapat menimbulkan risiko yang tinggi pula bagi perusahaan. Maka dari itu perlu diteliti lebih lanjut mengenai faktor atau variabel yang dapat memberikan pengaruh terhadap struktur modal dari perusahaan pertambangan.

Berdasarkan uraian latar belakang masalah sebelumnya, maka dapat dirumuskan pokok permasalahan sebagai berikut: 1) Apakah tingkat pertumbuhan berpengaruh signifikan terhadap struktur modal perusahaan pertambangan di BEI? 2) Apakah struktur aktiva berpengaruh signifikan terhadap struktur modal perusahaan pertambangan di BEI? 3) Apakah profitabilitas berpengaruh signifikan terhadap struktur modal perusahaan pertambangan di BEI? 4) Apakah likuiditas berpengaruh signifikan terhadap struktur modal perusahaan pertambangan di BEI?

Tujuan dari penelitian yaitu (1) Untuk mengetahui signifikansi pengaruh tingkat pertumbuhan terhadap struktur modal perusahaan pertambangan di BEI, (2) Untuk mengetaui signifikansi pengaruh struktur aktiva terhadap struktur modal perusahaan pertambangan di BEI, (3) Untuk mengetahui signifikansi pengaruh profitabilitas terhadap struktur modal perusahaan pertambangan di BEI, (4) Untuk mengetahui signifikansi pengaruh likuiditas terhadap struktur modal perusahaan pertambangan di BEI. Kegunaan teoritis dari penelitian ini adalah penelitian ini diharapkan mampu menjadi bukti empiris serta sumber referensi untuk penelitian selanjutnya mengenai struktur modal khususnya mengenai pengaruh tingkat pertumbuhan, struktur aktiva, profitabilitas dan likuiditas terhadap struktur modal, sedangkan kegunaan praktis dalam penelitian ini yaitu diharapkan dapat memberikan informasi dan bahan pertimbangan bagi perusahaan terutama bagi 
manajer keuangan sehubungan dengan keputusan dalam memilih alternatif sumber pendanaan dengan memperhatikan faktor-faktor yang mempengaruhi struktur modal.

Perusahaan dengan tingkat pertumbuhan yang relatif tinggi akan cenderung mengalami ketidakpastian yang lebih tinggi sehingga perusahaan akan memilih untuk mengurangi keinginan untuk menggunakan hutang dan menggunakan dana internalnya untuk menghindari risiko gagal bayar. Berdasarkan hal tersebut, apabila tingkat pertumbuhan mengalami peningkatan, maka struktur modal akan mengalami penurunan. Pernyataan tersebut diperkuat dengan studi empiris mengenai pengaruh tingkat pertumbuhan terhadap struktur modal seperti yang dilakukan oleh Alipour et al. (2015), Setyawan et al. (2016), serta Sari (2015) yang menunjukkan bahwa tingkat pertumbuhan memiliki pengaruh negatif dan signifikan terhadap struktur modal. Berdasarkan sejumlah hasil yang mendukung, maka dirumuskan hipotesis sebagai berikut:

$\mathrm{H}_{1}$ :Tingkat pertumbuhan memiliki pengaruh negatif dan signifikan terhadap struktur modal

Aktiva tetap merupakan aktiva yang peka terhadap risiko karena memiliki waktu perputaran yang yang panjang. Suatu perusahaan yang memiliki aktiva yang peka terhadap risiko dalam jumlah yang tinggi akan menggunakan pendanaan secara internal terebih dahulu dan mengurangi penggunaan modal asing. Berdasarkan hal tersebut maka semakin besar jumlah aktiva tetap yang dimiliki ole perusahaan maka perusahaan akan menggunakan modal sendiri, serta apabila memiliki aktiva lancar dalam jumlah yang tinggi maka akan digunakan pendanaan 
Made Yunitri Deviani, Pengaruh Tingkat Pertumbuhan, Struktur Aktiva...

dengan hutang jangka pendek. Beberapa hasil studi empiris menyatakan bahwa terdapat pengaruh positif dan signifikan antara struktur aktiva terhadap struktur modal seperti yang diungkapkan oleh Liem et al. (2013), serta Mandana dan Artini (2015). Berdasarkan sejumlah hasil yang mendukung, maka dirumuskan hipotesis sebagai berikut:

$\mathrm{H}_{2}$ :Struktur aktiva memiliki pengaruh positif dan signifikan terhadap struktur modal.

Berdasarkan Pecking order theory, perusahaan menyukai internal financing. Perusahaan yang memiliki tingkat profitabilitas yang tinggi lebih menyukai pendanaan secara internal terlebih dahulu. Jadi, jika profitabilitas dari suatu perusahaan mengalami peningkatan, maka struktur modal perusahaan akan mengalami penurunan seiring berkurangnya penggunaan hutang oleh perusahaan. Beberapa studi empiris mendukung pernyataan dari pecking order theory beberapa diantaranya yaitu penelitian yang dilakukan oleh Pattweekongka dan Napompech (2014), Juliantika dan Dewi (2016), Sheikh dan Wang (2011) serta Ananto (2015) menemukan hasil bahwa profitabilitas perusahaan memiliki pengaruh negatif dan signifikan terhadap struktur modal perusahaan. Berdasarkan sejumlah hasil yang mendukung, maka dirumuskan hipotesis sebagai berikut:

$\mathrm{H}_{3}$ : Profitabilitas memiliki pengaruh negatif dan signifikan terhadap struktur modal Berdasarkan pecking order theory, tingkat likuiditas yang tinggi akan cenderung menahan perusahaan untuk menggunakan hutang karena perusahaan yang memiliki likuiditas yang tinggi berarti memiliki dana internal yang tinggi sehingga perusahaan tersebut akan mengutamakan penggunaan dana internal 
daripada menggunakan dana eksternal. Jadi, perusahaan yang memiliki likuiditas yang tinggi, maka tingkat struktur modal perusahaan akan semakin rendah, dan demikian likuiditas perusahaan memiliki pengaruh negatif terhadap struktur modal perusahaan. Beberapa hasil studi empiris seperti penelitian yang dilakukan oleh Pattweekongka dan Napompech (2014), Ananto (2015) serta Juliantika dan Dewi (2016) menunjukkan bahwa likuiditas suatu perusahaan memiliki pengaruh negatif dan signifikan terhadap struktur modal suatu perusahaan. Berdasarkan sejumlah hasil yang mendukung, maka dirumuskan hipotesis sebagai berikut:

$\mathrm{H}_{4}$ : Likuiditas memiliki pengaruh negatif dan signifikan terhadap struktur modal

\section{METODE PENELITIAN}

Penelitian ini menggunakan pendekatan kuantitatif dengan desain asosiatif. Penelitian yang bersifat asosiatif menguji pengaruh suatu variabel dengan variabel lainnya yang dalam penelitian ini untuk mengetahui pengaruh tingkat pertumbuhan, struktur aktiva, profitabilitas dan likuiditas terhadap struktur modal. Penelitian ini dilakukan pada perusahaan sektor pertambangan yang terdaftar di Bursa Efek Indonesia (BEI) periode 2012-2015 yang dapat diakses melalui situs resmi Bursa Efek Indonesia (BEI) yaitu www.idx.co.id. Variabel terikat yang digunakan dalam penelitian ini yaitu struktur modal yang disimbolkan dengan Y. Variabel bebas dalam penelitian ini yaitu tingkat pertumbuhan disimbolkan dengan X1, struktur aktiva disimbolkan dengan X2, profitabilitas disimbolkan dengan X3, dan likuiditas disimbolkan dengan X4. 
Made Yunitri Deviani, Pengaruh Tingkat Pertumbuhan, Struktur Aktiva...

Struktur modal pada penelitian ini diukur dengan menggunakan Long Term Debt to Equity Ratio (LTDER) yang membandingkan hutang jangka panjang yang dimiliki perusahaan dengan total modal sendiri perusahaan dari tahun 2012-2015 pada perusahaan pertambangan di Bursa Efek Indonesia. Long Term Debt to Equity Ratio (DER) dinyatakan dalam persentase dengan rumus sebagai berikut (Wiagustini, 2014:88):

Long Term Debt to Equity Ratio= $\frac{\text { Hutang Jangka Panjang }}{\text { Total Modal Sendiri }} \times 100 \%$

Pertumbuhan penjualan perusahaan pada penelitian ini yaitu perbandingan antara penjualan periode $\mathrm{t}$ dikurangi penjualan periode $\mathrm{t}-1$ dengan penjualan $\mathrm{t}-1$ perusahaan dari tahun 2012-2015 pada perusahaan pertambangan di Bursa Efek Indonesia yang dinyatakan dalam persentase serta dapat dinyatakan dalam rumus sebagai berikut (Harahap, 2016:309):

Tingkat pertumbuhan $=\frac{\text { Penjualan }_{\mathrm{t}}-\text { Penjualan }_{\mathrm{t}-1}}{\text { Penjualan }_{\mathrm{t}-1}} \times 100 \%$

Pada penelitian ini, struktur aktiva dihitung dengan membandingkan aktiva lancar dengan aktiva tetap dimiliki oleh perusahaan dari tahun 2012-2015 pada perusahaan pertambangan di Bursa Efek Indonesia.Struktur aktiva dapat dihitung dengan menggunakan rumus sebagai berikut (Riyanto, 2011:22):

Struktur Aktiva $=\frac{\text { Aktiva Lancar }}{\text { Aktiva Tetap }} \times 100 \%$

Profitabilitas pada penelitian ini diproksikan dengan Return on Equity (ROE) yang menunjukkan persentase labaobersih yang diperolehibila diukur dari modal sendiri perusahaan dari tahun 2012-2015 pada perusahaan pertambangan di 
BursaiEfekiIndonesia. Return on Equity dapat dihitung dengan menggunakan rumus sebagai berikut (Sartono, 2014:124):

ROE $=\frac{\text { Laba Setelah Pajak }}{\text { Modal Sendiri }} x 100 \%$

Likuiditas pada penelitian ini dihitung dengan Current ratio, yang membandingkan antara aktiva lancar terhadap pasiva lancar dari tahun 2012-2015 pada perusahaan pertambangan di Bursa Efek Indonesia yang dinyatakan dalam persentase. Current Ratio dapat dirumuskan sebagai berikut (Sartono, 2014:116):

Current Ratio $=\frac{\text { Aktiva Lancar }}{\text { Pasiva Lancar }} \times 100 \%$

Populasi pada penelitian ini yaitu perusahaan sektor pertambangan yang terdaftar di BEI periode 2012-2015 yaitu sebanyak 43 perusahaan. Metode penentuan sampel yang digunakan dalam penelitian ini adalah dengan teknik purposive sampling. Adapun kriteria yang ditentukan yaitu 1) Perusahaan pertambangan yang terdaftar di BEI periode 2012-2015, 2) Perusahaan pertambangan yang terdaftar di BEI periode 2012-2015 yang mempublikasikan laporan keuangan tahunan berturut-turut dari tahun 2012-2015, 3) Perusahaan pertambangan yang terdaftar di BEI periode 2012-2015 yang menyediakan data lengkap yang diperlukan dalam penelitian ini.

Berdasarkan kriteria yang telah ditentukan tersebut maka, jumlah sampel pada penelitian ini yaitu 23 perusahaan.

Jenis data yang digunakan dalam penelitian ini yaitu data kuantitatif dan data kualitatif. Data sekunder pada penelitian ini didapatkan dari website Bursa Efek Indonesia yang diakses melalui www.idx.co.id. Metode pengumpulan data yang 
pada penelitian ini yaitu metode observasi non partisipan. Teknik analisis data yang digunakan pada penelitian ini yaitu analisis regresi linear berganda. Model regresi linear berganda yang dimaksud dirumuskan sebagai berikut (Utama, 2014:77):

$$
\mathrm{Y}=\alpha+\beta_{1} \mathrm{X}_{1}+\beta_{2} \mathrm{X}_{2}+\beta_{3} \mathrm{X}_{3}+\beta_{4} \mathrm{X}_{4}+\varepsilon_{\mathrm{i}}
$$

Dimana :

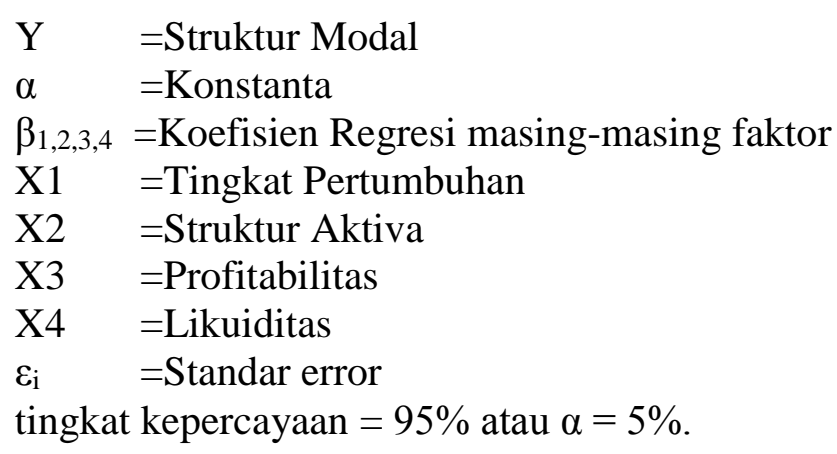

\section{HASIL DAN PEMBAHASAN}

Tabel 2

Analisis Statistik Deskriptif

\begin{tabular}{lrrrrr}
\hline & N & \multicolumn{1}{c}{ Minimum } & Maximum & \multicolumn{1}{c}{ Mean } & \multicolumn{1}{c}{ Std. Deviation } \\
\hline Struktur Modal & 92 &, 66 & 358,01 & 45,6750 & 56,06052 \\
Tk. Pertumbuhan & 92 & $-95,93$ & 125,58 & $-1,7688$ & 34,63507 \\
Struktur Aktiva & 92 &, 45 & 157877,37 & 2285,2054 & 16565,35863 \\
Profitabilitas & 92 & $-161,89$ & 43,10 & 2,3025 & 24,91131 \\
Likuiditas & 92 & 20,50 & 691,36 & 197,9097 & 114,32733 \\
Valid N (listwise) & 92 & & & & \\
Sumber: Data Diolah, 2017 & & & & &
\end{tabular}

Berdasarkan hasil pengujian tersebut diketahui bahwa variabel $\mathrm{Y}$ atau struktur modal perusahaan terendah yaitu 0,66 yang dimiliki oleh PT Harum Energy Tbk. dan nilai tertinggi 358,01 yang dimiliki oleh PT Bayan Resources Tbk. Tingkat pertumbuhan perusahaan terendah yaitu $-95,93$ persen yang dimiliki oleh PT Cita Mineral Investindo Tbk. dan nilai tertinggi 125,58 persen yang dimiliki 
oleh PT Bara Jaya Internasional Tbk. Struktur aktiva perusahaan terendah yaitu 0,45 persen yang dimiliki oleh PT Citatah Tbk. dan nilai tertinggi 157877,37 persen yang dimiliki oleh PT Benakat Integra Tbk. Profitabilitas perusahaan terendah yaitu -161,89 persen yang dimiliki oleh PT Mitra Investindo Tbk. dan nilai tertinggi 43,10 persen yang dimiliki oleh PT Indo Tambang Raya Megah Tbk. likuiditas perusahaan terendah yaitu 20,50 persen yang dimiliki oleh PT Atlas Resources Tbk. dan nilai tertinggi 691,36 persen yang dimiliki oleh PT Harum Energy Tbk.

Analisis regresi linear berganda digunakan untuk mengetahui pengaruh tingkat pertumbuhan, struktur aktiva, profitabilitas, dan likuiditas terhadap struktur modal perusahaan pertambangan di Bursa Efek Indonesia.

\section{Tabel 3}

\section{Hasil Analisis Regresi Linear Berganda}

\begin{tabular}{lll}
\hline \multicolumn{1}{c}{ Variabel } & Koefisien Regresi & Sig. \\
\hline (Constant) & 64,92372 &, 000 \\
Tk. Pertumbuhan &,- 28288 &, 018 \\
Struktur Aktiva &,- 00015 &, 455 \\
Profitabilitas &,- 72463 &, 002 \\
Likuiditas &,- 10421 &, 001 \\
\hline R Square $=0,296$ & & F $=9,152$ \\
\hline Adj. R Square $=0,264$ & & Sig. $=0,000$ \\
\hline Sumber: Data Diolah, 2017 & &
\end{tabular}

Berdasarkan hasil analisis regresi linear berganda pada Tabel 3 maka persamaan regresi yang digunakan dalam penelitian ini yaitu.

$Y=64,92372-0,28288 X_{1}-0,00015 X_{2}-0,72463 X_{3}-0,10421 X_{4}$

Keterangan:

$\begin{array}{ll}\mathrm{Y} & =\text { StrukturrModal } \\ \alpha & =\text { Konstanta } \\ \mathrm{X} 1 & =\text { Tingkat Pertumbuhan } \\ \mathrm{X} 2 & =\text { Struktur Aktiva } \\ \mathrm{X} 3 & =\text { Profitabilitas } \\ \mathrm{X} 4 & =\text { Likuiditas } \\ \varepsilon_{\mathrm{i}} & =\text { Standar error }\end{array}$


Made Yunitri Deviani, Pengaruh Tingkat Pertumbuhan, Struktur Aktiva...

$\alpha$ atau konstanta sebesar 64,92372 memiliki arti bahwa jika nilai dari variabel tingkat pertumbuhan, struktur aktiva, profitabilitas, dan likuiditas sama dengan nol,imaka nilai struktur modal sama dengan 64,92372. $\beta_{1}$ merupakan koefisien regresi dari variabel tingkat pertumbuhan yaitu sebesar $-0,28288$ yang memiliki arti bahwa apabila tingkat pertumbuhan mengalami peningkatan sebesar $1 \%$ maka nilai dari struktur modal akan mengalami penurunan sebesar 28,288\% dengan asumsi bahwa variabelibebas lainnyaakonstan.

$\beta_{2}$ merupakan koefisien regresi dari variabel struktur aktiva yaitu sebesar 0,00015 yang memiliki arti bahwa apabila struktur aktiva mengalami peningkatan sebesar $1 \%$ makaanilai dari struktur modal akan mengalami penurunan sebesar 0,0015\% dengan asumsi bahwa variabel bebas lainnya adalah tetap atau konstan. $\beta_{3}$ merupakan koefisien regresi dari variabel profitabilitas yaitu sebesar $-0,72463$ yang memiliki arti bahwa apabila tingkat profitabilitas perusahaan mengalami peningkatan sebesar $1 \%$ maka nilai dari struktur modal akan mengalami penurunan sebesar $72,463 \%$ dengan asumsi bahwa variabel independen atau variabel bebas lainnya tetap atau konstan.

$\beta_{4}$ merupakan koefisien regresi dari variabel likuiditas yaitu sebesar -0,10421 yang memiliki arti, jika likuiditas mengalami peningkatan sebesar $1 \%$ maka nilai struktur modal perusahaan akan mengalami penurunan sebesar $10,421 \%$ dengan asumsi bahwa variabel independen atau variabel bebas lainnya tetap atau konstan.

Hasil analisis tersebut masih perlu ditinjau lebih lanjut dengan hasil uji kelayakan model (uji F), koefisien determinasi $\left(\mathrm{R}^{2}\right)$, dan uji secara parsial. 
Tabel 4

Hasil Uji Normalitas

\begin{tabular}{lr}
\hline & \multicolumn{2}{c}{ Unstandardized } \\
& Residual \\
\hline Kolmogorov-Smirnov Z & 1,335 \\
Asymp. Sig. (2-tailed) &, 057 \\
\hline Sumber: Data Diolah, 2017 &
\end{tabular}

Berdasarkan tabel 4 diperoleh nilai Asymp. Sig (2-tailed) sebesar 0,057 atau

5,7 persen yang lebih dari 0,05 atau 5 persen maka dapat dikatakan bahwa data terdistribusi normal.

\section{Tabel 5}

Hasil Uji Autokorelasi

\begin{tabular}{lrrrrrr}
\hline Model & R & R Square & $\begin{array}{l}\text { Adjusted R } \\
\text { Square }\end{array}$ & $\begin{array}{l}\text { Std. Error of the } \\
\text { Estimate }\end{array}$ & $\begin{array}{l}\text { Durbin- } \\
\text { Watson }\end{array}$ \\
\hline 1 &, $544^{\mathrm{a}}$ &, 296 &, 264 & & 31,73282 & 2,167 \\
\hline
\end{tabular}

Sumber: Data Diolah, 2017

Berdasarkan Tabel 5 yang menunjukkan nilai Durbin Watson sebesar 2,167 dengan nilai dl sebesar 1.5713 dan nilai du yaitu sebesar 1,7523 sehingga dapat diperoleh nilai 4-dl sebesar 2,4287 dan nilai 4-du sebesar 2,2477. Nilai DurbinWatson sebesar 2,167 berada diantara nilai du dan nilai 4-du $(1,7523<2,167<2,2477)$ maka hasil pengujian dengan Durbin-Watson menunjukkan bahwa hasil berada pada daerah tidak ada autokorelasi yang miliki arti bahwa model regresi pada penelitian ini tidak terdapat gejala autokorelasi.

Tabel 6

Hasil Uji Multikolinearitas

\begin{tabular}{llll}
\hline No & Variabel & Nilai Tolerance & Nilai VIF \\
\hline 1. & Tingkat pertumbuhan & 0,910 & 1,099 \\
2. & Struktur Aktiva & 0,988 & 1,012 \\
3. & Profitabilitas & 0,890 & 1,123 \\
4. & Likuiditas & 0,921 & 1,086 \\
\hline
\end{tabular}

Sumber: Data Diolah, 2017

Hasil uji multikolinearitas pada tabel 6 menunjukkan nilai tolerance masingmasing variabel dari 0,10 atau 10 persen serta nilai VIF lebih kecil dari 10, dapat 
Made Yunitri Deviani, Pengaruh Tingkat Pertumbuhan, Struktur Aktiva...

dinyatakan bahwa model regresi pada penelitian ini bebas dari gejala multikolinearitas.

Tabel 7

Hasil Uji Heteroskedastisitas

\begin{tabular}{clll}
\hline No & Variabel & Sig. & Keterangan \\
\hline 1. & Tingkat pertumbuhan & 0,713 & Bebas heteroskedastisitas \\
2. & Struktur Aktiva & 0,469 & Bebas heteroskedastisitas \\
3. & Profitabilitas & 0,892 & Bebas heteroskedastisitas \\
4. & Likuiditas & 0,097 & Bebas heteroskedastisitas \\
Sumber: & Data Diolah, 2017 & &
\end{tabular}

Berdasarkan tabel 7 menunjukkan bahwa seluruh variabel bebas dalam penelitian ini memiliki nilai signifikansi yang lebih besar dari 0,05. Hasil uji heteroskedastisitas tersebut menunjukkan bahwa model regresi dalam penelitian ini terbebas dari gejala heteroskedastisitas.

$R$ square pada tabel 3 yaitu sebesar 0,296 atau 29,6\%. Hasil tersebut memiliki arti bahwa hanya 29,6\% variasi dari variabel terikat yaitu struktur modal yang dapat dijelaskan oleh variasi variabel bebas yaitu tingkat pertumbuhan, struktur aktiva, profitabilitas, dan likuiditas. Sisanya 70,4\% dijelaskan oleh faktor atau variabel lainnya yang tidak dimasukkan dalam model analisis.

Nilai Sig. F pada tabel 3 sebesar 0,000 yang lebih kecil dari tingkat 0,05 memiliki arti bahwa, variabel bebas tingkat pertumbuhan, struktur aktiva, profitabilitas, dan likuiditas berpengaruh secara serempak terhadap yaitu struktur modal.

\section{Tabel 8}

Ringkasan Hasil Uji t

\begin{tabular}{llccc}
\hline No. & Variabel & Koefisien Regresi & $\mathbf{t}_{\text {hitung }}$ & Sig. \\
\hline 1. & Tingkat Pertumbuhan &,- 28288 & $-2,403$ & 0,018 \\
2. & Struktur Aktiva &,- 00015 & $-0,751$ & 0,455 \\
3. & Profitabilitas &,- 72463 & $-3,217$ & 0,002 \\
4. & Likuiditas &,- 10421 & $-3,352$ & 0,001 \\
\hline
\end{tabular}

Sumber: Data Diolah, 2017 
Tabel 8 menunjukkan bahwa nilai sig. sebesar 0,018 lebih kecil dari tingkat signifikansi sebesar 0,05 , nilai koefisien regresi variabel tingkat pertumbuhan sebesar $-0,28288$ serta nilai t hitung sebesar $-2,403$ dengan tanda negatif memiliki arti bahwa tingkat pertumbuhan memiliki pengaruh negatif dan signifikan terhadap struktur modal perusahaan pertambangan di Bursa Efek Indonesia periode 20122015. Hasil ini menunjukkan bahwa $\mathrm{H}_{0}$ ditolak dan $\mathrm{H}_{1}$ yang menyatakan tingkat pertumbuhan memiliki pengaruh negatif signifikan terhadap struktur modal diterima.

Tabel 8 menunjukkan bahwa nilai sig. sebesar 0,455 lebih besar dari 0,05, nilai koefisien regresi struktur aktiva sebesar -0,00015, serta nilai t hitung sebesar 0,751 dengan tanda negatif memiliki arti bahwa struktur aktiva memiliki pengaruh negatif tidak signifikan terhadap struktur modal perusahaan pertambangan di Bursa Efek Indonesia periode 2012-2015. Hasil ini menunjukkan bahwa $\mathrm{H}_{0}$ diterima dan $\mathrm{H}_{1}$ yang menyatakan struktur aktiva memiliki positif signifikan terhadap struktur modal dalam penelitian ini ditolak.

Tabel 8 menunjukkan bahwa nilai sig. sebesar 0,002 lebih kecil dari tingkat signifikansi yaitu sebesar 0,05, nilai koefisien regresi sebesar $-0,72463$ serta nilai t hitung sebesar -3,217 dengan tanda negatif memiliki arti bahwa profitabilitas memiliki pengaruh negatif dan signifikan terhadap struktur modal perusahaan pertambangan di Bursa Efek Indonesia periode 2012-2015. Hasil ini menunjukkan bahwa $\mathrm{H}_{0}$ ditolak dan $\mathrm{H}_{1}$ yang menyatakan profitabilitas memiliki pengaruh negatif signifikan terhadap struktur modal dalam penelitian ini diterima. 
Tabel 8 menunjukkan bahwa nilai sig. sebesar 0,001 lebih kecil dari 0,05, nilai koefisien regresi sebesar -0,10421 serta nilai t hitung sebesar -3,352 dengan tanda negatif memiliki arti bahwa likuiditas perusahaan berpengaruh negatif dan signifikan terhadap struktur modal perusahaan pertambangan di Bursa Efek Indonesia periode 2012-2015. Hasil ini menunjukkan bahwa $\mathrm{H}_{0}$ ditolak dan $\mathrm{H}_{1}$ yang menyatakan likuiditas memiliki pengaruh negatif signifikan terhadap struktur modal dalam penelitian ini diterima.

\section{Pengaruh Tingkat Pertumbuhan terhadap Struktur Modal}

Berdasarkan hasil penelitian yang menunjukkan bahwa tingkat pertumbuhan memiliki pengaruh negatif dan signifikan terhadap struktur modal perusahaan pertambangan di Bursa Efek Indonesia pada periode 2012-2015 sehingga hipotesis dalam penelitian ini diterima. Hasil penelitian ini mencerminkan bahwa apabila tingkat pertumbuhan perusahaan meningkat, maka struktur modal dari perusahaan akan menurun. Hasil penelitian pada penelitian ini diperkuat oleh hasil penelitian sebelumnya yang dilakukan oleh oleh Alipour et al. (2015), Saleem et al. (2013), Chadha dan Sharma (2015), serta Sari (2015) yang menunjukkan bahwa tingkat pertumbuhan memiliki pengaruh negatif dan signifikan pada struktur modal.

\section{Pengaruh Struktur Aktiva terhadap Struktur Modal}

Berdasarkan hasil yang diperoleh dalam penelitian ini, menunjukkan bahwa struktur aktiva berpengaruh negatif tidak signifikan terhadap struktur modal perusahaan pertambangan di BEI periode 2012-2015. Arah negatif dari hasil dalam penelitian ini memiliki arti bahwa semakin tinggi struktur aktiva yang dicerminkan melalui perbandingan antara aktiva lancar dengan aktiva tetap, maka struktur modal 
perusahaan akan semakin meningkat. Hasil penelitian yang tidak signifikan menunjukkan bahwa dalam mengambil keputusan untuk struktur modal, maka perusahaan pertambangan di BEI pada periode 2012-2015 tidak terlalu mempertimbangkan struktur aktiva dalam pengambilan keputusan struktur modal. Hasil yang diperoleh dalam penelitian ini diperkuat dengan hasil pada penelitian terdahulu yang dilakukan oleh Hamidah et al. (2016) dan Widodo (2013) yang menunjukkan struktur aktiva memiliki pengaruh negatif namun tidak signifikan pada struktur modal perusahaan.

\section{Pengaruh Profitabilitas terhadap Struktur Modal}

Berdasarkan hasil yang diperoleh dalam penelitian ini menunjukkan profitabilitas memiliki negatif dan signifikan terhadap struktur modal perusahaan pertambangan di BEI pada periode 2012-2015, sehingga hipotesis dalam penelitian ini diterima. Pengaruh profitabilitas pada struktur modal dengan arah negatif menunjukkan bahwa apabila profitabilitas perusahaan mengalami peningkatan maka struktur modal perusahaan akan semakin menurun. Sebaliknya, apabila profitabilitas perusahaan menurun maka struktur modal perusahaan akan meningkat. Hasil penelitian ini diperkuat dengan beberapan hasil dari penelitian terdahulu yang dilakukan oleh Pattweekongka dan Napompech (2014), Juliantika dan Dewi (2016), Ananto (2015), Masnoon dan Abiha (2014), chen dan chen (2011), Chadha dan Sharma (2015), serta Cortez dan Susanto (2012) yang menemukan bahwa profitabilitas berpengaruh negatif dan signifikan pada struktur modal. 


\section{Pengaruh Likuiditas terhadap Struktur Modal}

Berdasarkan hasil yang diperoleh dalam penelitian ini menunjukkan bahwa likuidtas berpengaruh negatif dan signifikan pada struktur modal perusahaan pertambangan di BEI pada periode 2012-2015, sehingga hipotesis dalam penelitian ini diterima. Pengaruh likuiditas terhadap struktur modal yang menunjukkan arah negatif memiliki arti bahwa apabila likuiditas perusahaan meningkat maka struktur modal perusahaan akan menurun. Sebaliknya, apabila tingkat likuiditas perusahaan menurun maka struktur modal perusahaan akan meningkat. Hasil yang diperoleh dalam penelitian ini diperkuat dengan beberapa hasil dari penelitian sebelumnya yang dilakukan oleh Sheikh dan Wang (2011) Pattweekongka dan Napompech (2014), Masnoon dan Abiha (2014), Ananto (2015), Ramlall (2009), serta Juliantika dan Dewi (2016) yang menyatakan bahwa likuiditas memiliki pengaruh negatif dan signifikan pada struktur modal.

\section{Implikasi Hasil Penelitian}

Implikasi penelitian ini menekankan pada manfaat nyata hasil penelitan bagi perusahaan untuk menentukan keputusan struktur modal dengan memperhatikan faktor yang mempengaruhi. Berdasarkan hasil penelitian menunjukkan tingkat pertumbuhan memiliki pengaruh negatif dan signifikan pada struktur modal. Hasil penelitian tersebut mengindikasikan bahwa, untuk menentukan struktur modal, perusahaan pertambangan harus memperhatikan tingkat pertumbuhan perusahaan agar mampu terhindar dari risiko dan kesulitan keuangan, karena penurunan pertumbuhan penjualan akan meningkatkan penggunaan hutang jangka panjang sehingga risiko akan semakin meningkat. 
Berdasarkan hasil dalam penelitian ini menunjukkan struktur aktiva memiliki pengaruh negatif namun tidak signifikan pada struktur modal perusahaan. Struktur aktiva meskipun memiliki pengaruh yang tidak signifikan pada struktur modal perusahaan, namun perusahaan tetap perlu memperhatikan struktur aktiva dari perusahaan tersebut.

Berdasarkan hasil penelitian, menunjukkan profitabilitas memiliki pengaruh negatif dan signifikan terhadap struktur modal perusahaan. Berdasarkan hasil penelitian tersebut perusahaan perlu memperhatikan tingkat profitabilitas perusahaan agar mampu menekan penggunaan hutang, serta menggunakan sumber dana internal yang tersedia sebelum mengambil keputusan untuk menggunakan hutang. Penggunaan hutang dalam jumlah yang rendah dapat membuat perusahaan terhindar dari risiko yang ditimbulkan oleh penggunaan hutang yang dapat menimbulkan dampak kesulitan keuangan bagi perusahaan.

Berdasarkan hasil penelitian menunjukkan bahwa likuiditas berpengaruh negatif dan signifikan terhadap struktur modal perusahaan. Berdasarkan hasil penelitian tersebut, maka perusahaan harus memperhatikan likuiditas perusahaan. Ketersediaan dana dalam perusahaan perlu dijaga agar perusahaan mampu untuk menekan penggunaan hutang. Dana internal yang tersedia dalam perusahaan juga sebaiknya perlu dijaga agar tidak terlalu banyak dana yang menganggur dalam perusahaan, sehingga kesempatan untuk berinvestasi juga akan berkurang. Penekanan penggunaan hutang juga mampu menghindari risiko yang ditimbulkan dari penggunaan hutang. 


\section{SIMPULAN DAN SARAN}

Berdasarkan hasil penelitian serta pembahasan yang telah dijelaskan tentang pengaruh tingkat pertumbuhan, struktur aktiva, profitabilitas, dan likuiditas terhadap struktur modal, maka dapat diambil simpulan sebagai berikut:1) Tingkat pertumbuhan memiliki pengaruh negatif dan signifikan terhadap struktur modal perusahaan pertambangan di Bursa Efek Indonesia 2) Struktur aktiva memiliki pengaruh negatif namun tidak signifikan terhadap struktur modal perusahaan pertambangan di Bursa Efek Indonesia 3) Profitabilitas memiliki pengaruh negatif dan signifikan terhadap struktur modal perusahaan pertambangan di Bursa Efek Indonesia 4) Likuiditas memiliki pengaruh negatif dan signifikan terhadap struktur modal perusahaan pertambangan di Bursa Efek Indonesia.

Berdasarkan simpulan yang telah dikemukakan maka dapat disarankan beberapa hal sebagai berikut: Berdasarkan simpulan mengenai penelitian ini, maka dapat disarankan hal-hal sebagai berikut: 1) Perusahaan dalam mengambil keputusan penentuan struktur modal, baik dengan penggunaan hutang maupun penggunaan modal sendiri sebaiknya mempertimbangkan faktor-faktor yang mempengaruhi struktur modal seperti tingkat pertumbuhan, profitabilitas, serta likuiditas dari perusahaan. Perusahaan perlu meningkatkan pertumbuhan perusahaan yaitu pertumbuhan penjulan perusahaan yang tidak hanya dominan pada ekspor,melainkan perlu menambah pangsa pasar domestik. Profitabilitas serta likuiditas perusahaan juga perlu ditingkatkan. Peningkatan pertumbuhan, profitabilitas, serta likuiditas perusahaan dapat menurunkan struktur modal perusahaan sehingga dapat menurunkan risiko perusahaan yang dapat 
menimbulkan kesulitan keuangan. 2) Perusahaan dalam mengambil keputusan penentuan struktur modal, selain mempertimbangkan faktor-faktor seperti tingkat pertumbuhan, profitabilitas, dan likuiditas, perusahaan juga sebaiknya memperhatikan faktor lainnya seperti pajak, ukuran perusahaan, serta kondisi ekonomi makro seperti tingkat suku bunga dan inflasi yang dapat mempengaruhi struktur modal bagi perusahaan.

\section{REFERENSI}

Akbar, Ume Salma dan Niaz Ahmed Bhutto. 2012. Determinants and Policies of Capital Structure in The Non-Financial Firms (Personal Care Goods) of Pakistan. Asian Journal of Business and Management Sciences, 2 (2):27-25.

Alipour, Mohammad, Mir Farhad Seddigh Mohammadi, dan Hojjatollah Derakhshan. 2015. Determinants of Capital Structure: An Empirical Study of Firms in Iran. International Journal of Law and Management, 57 (1):5383.

Ananto, M. 2015. Pengaruh Profitabilitas, Kepemilikan Institusional, Growth Opportunity dan Likuiditas Terhadap Struktur Modal pada Perusahaan Manufaktur yang Terdaftar Di Bursa Bursa Efek Indonesia. Skripsi. Jurusan Manajemen Universitas Negeri Yogyakarta.

Asosiasi Pertambangan Batubara Indonesia. 2017. Indonesian Coal Production, Exports, Domestic Sales and Average of Coal Price Based on ICPR/HBS Periods 2009-2015. http://www.apbi-icma.org/. (Diunduh tanggal 20 Maret 2017).

Asosiasi Pertambangan Indonesia. 2017. Potensi dan Tantangan Pertambangan di Indonesia. http://www.ima-api.com. (Diunduh tanggal 15 Oktober 2017).

Association of Indonesian Environmental Observes. 2016. Indonesian Oil Reserves - Resources. http://www.hpli.org/tambang.php. (Diunduh tanggal tanggal 20 Maret 2017).

Badan Pusat Statistik. 2017. Produk Domestik Bruto. http://www.bps.go.id/. (Diunduh tanggal 19 Maret 2017).

Bhawa, Ida Bagus Made Dwija Dan Made Rusmala Dewi. 2015. Pengaruh Ukuran Perusahaan, Likuiditas, Profitabilitas, Dan Risiko Bisnis Terhadap Struktur Modal Perusahaan Farmasi. E-Jurnal Manajemen Universitas Udayana, 4 (7):1949-1966. 
Brigham, Eugene, F., dan Houston Joel, F. 2011. Dasar-Dasar Manajemen Keuangan. Edisi kesebelas. Jilid kedua. Jakarta: Salemba Empat.

Brigham, Eugene, F., dan Houston Joel, F. 2015. Dasar-Dasar Manajemen Keuangan. Edisi kesebelas. Jilid satu. Jakarta: Salemba Empat.

Bursa Efek Indonesia. 2017. IDX Yearly Statistics 2016. http://www.idx.co.id/. (Diunduh tanggal 18 Maret 2017).

Chadha, Saurabh dan Anil K. Sharma. 2015. Determinants of Capital Structure: An Empirical Evaluation from India. Journal of Advances inManagement Research, 12 (1):3-14.

Chen, Shun-Yu dan Li-Ju Chen. 2011. Capital structure determinants: An empirical study in Taiwan. African Journal of Business Management, 5 (27):1097410983.

Cortez, Michael Angelo., dan Stevie, Susanto. 2012. The Determinants Of Corporate Capital Structure: Evidence From Japanese Manufacturing Companies. Journal of International Business Research, 11 (3):121-134.

Dewi, Ni Kadek Tika Sukma dan I Made Dana. 2017. Pengaruh Growth Opportunity, Likuiditas, Non-Debt Tax Shield dan Fixed Asset Ratio terhadap Struktur Modal. E-Jurnal Manajemen Universitas Udayana, 6 (2):772-801.

Gamaliel, Joshua dan Luh Komang Sudjarni. 2015. Pengaruh Profitabilitas, Ukuran Perusahaan, dan Struktur Aktiva terhadap Struktur Modal pada Perusahaan Transportasi di Bursa Efek Indonesia. E-Jurnal Manajemen, 4 (1):59-74.

Ghozali, Imam. 2016. Aplikasi Analisis Multivariate dengan Program IBM SPSS 23. Semarang: Badan Penerbit Universitas Dipoegoro.

Hadianto, Bram dan Christian Tayana, 2010. Pengaruh Risiko Sistematik, Struktur aktiva, Profitabilitas, dan Jenis Perusahaan terhadap Struktur Modal Emiten Sektor Pertambangan. Jurnal Akuntansi, 2 (1):15-39.

Hamidah, Diana Iswara, dan Umi Mardiyati. 2016. The Effect of Profitability, liquidity, Growth Sales, Operating Leverage and Tangibility on Capital Structure (Evidence from Manufacture Firm Listed on Indonesia Stock Exchange in 20112014). Jurnal Riset Manajemen 7 (1) : 96-116.

Hanafi, Mamduh M. dan Halim, Abdul, 2009, Analisa Laporan Keuangan, UPP AMP YKPN, Yogyakarta.

Harahap, Sofyan Syafri. 2016. Analisis Kritis atas Laporan Keuangan. Jakarta: PT. Raja Grafindo Persada. 
Husnan, Suad. 2012. Manajemen Keuangan Teori dan Penerapan (Keputusan Jangka Panjang). Yogyakarta : BPFE

Juliantika, Ni Luh Ayu Amanda Mas dan Made Rusmala Dewi. 2016. Pengaruh Profitabilitas, Ukuran Perusahaan, Likuiditas, dan Risiko Bisnis terhadap Struktur Modal Pada Perusahaan Property Dan Realestate. E-Jurnal Manajemen Universitas Udayana, 5 (7):4161 - 4192.

Khairin, Mochamad Yahdi dan Puji Harto. 2014. Pengaruh Growth Opportunity, Profitabilitas, Fixed Asset Ratio Dan Risiko Pasar Terhadap Struktur Modal. Diponegoro Journal Of Accounting , 3 (2):1-12.

Kartika, I Komang Sunarta dan Made Dana. 2015. Analisis Pengaruh Profitabilitas, Likuiditas, Ukuran Perusahaan, dan Tingkat Pertumbuhan terhadap Struktur Modal Perusahaan Food And Beverages yang Terdaftar di Bursa Efek Indonesia. E-Jurnal Manajemen, 4 (3):606-625.

Kaur, Inderjit. 2014. Capital Structure Decision -Theoretical Underpinnings and Empirical Evidences. Journal of Commrce \& Accounting Research, 3 (1):40-48.

Kementerian Perindustrian Republik Indonesia. 2017. Perkembangan Ekspor Indonesia Berdasarkan Sektor. http://kemenperin.go.id. (Diunduh tanggal 24 September 2017).

Liem, Jemmi,Halim., Warner, Ria, Murhadi., dan Bertha, Silvia, Sutejo. 2013. Faktor-Faktor Yang Mempengaruhi Struktur Modal Pada Industri Consumer Good Yang Terdaftar di BEI Periode 2007-2011. Jurnal Ilmiah Mahasiswa Universitas Surabaya, 2 (1):1-11.

Liestyasih, Luh Putu Erma dan I Putu Yadnya. 2015. Pengaruh Operating Leverage, Ndts, Struktur Aktiva, dan Growth Opportunity terhadap Struktur Modal. E-Jurnal Manajemen Universitas Udayana, 4 (2):607-621.

Mandana, I Wayan Martha dan Luh Gede Sri Artini. 2015. Pengaruh Struktur Aktiva, Tingkat Pertumbuhan Penjualan, Profitabilitas dan Pertumbuhan Perusahaan terhadap Struktur Modal pada PT. PLN (Persero) Distribusi Bali Periode 2004-2011. E-Jurnal Manajemen Universitas Udayana, 4 (7):17981815.

Masnoon, Maryam.,dan Abiha, Saeed. 2014. Capital Structure Determinants Of Kse Listed Automobile Companies. European Scientific Journal, 10 (13) :451-461.

Modigliani, F., \& Miller, M.H. (1958). The Cost of Capital, Corporation Finance and the Theory of Investment. The American Economic Review, 48 (3):261-297. 
Modigliani, F., \& Miller, M.H. (1963). Corporate Income Taxes and the Cost of Capital: A Correction. The American Economic Review, 53 (3):433-443.

Murhadi, Werner Ria. 2011. Determinan Struktur Modal: Studi di Asia Tenggara. Jurnal Manajemen dan Kewirausahaan, 13 (2):91-98.

Pattweekongka, Supawadee dan Kulkanya Napompech. 2014. Determinants of Capital Structure: Evidence from Thai Lodging Companies. International Journal of Arts \& Sciences, 7 (4):45-52.

Putra, Dwi Ema dan I Ketut Wijaya Kesuma. 2014. Pengaruh Profitabilitas, Likuiditas, Ukuran, Pertumbuhan Terhadap Struktur Modal Industri Otomotif di BEI. E-Jurnal Manajemen Universitas Udayana, 3 (6):17531766.

Putri, Meidera Elsa Dwi. 2012. Pengaruh Profitabilitas, Struktur Aktiva dan Ukuran Perusahaan terhadap Struktur Modal pada Perusahaan Manufaktur Sektor Industri Makanan dan Minuman yang Terdaftar di Bursa Efek Indonesia (BEI). Jurnal Manajemen, 1 (1):1-10.

Ramlall, Indranarain. 2009. Determinant of Capital Structure Among Non-Quoted Mauritian Firms Under Specificity of Leverage: Looking for a Modified Pecking Order Theory. International Research Journal of Finance and Economics, 31 (31):83-92.

Rasoolpur, Gurnam, Singh. 2012. An Empirical Analysis Of Capital Structure Determinants: Evidence From The Indian Corporate Sektor. International Journal of Management \& Information Technology, 1 (3):1-12.

Riyanto, Bambang. 2011. Dasar-dasar Pembelanjaan Perusahaan. Edisi 4 Cetakan Ketujuh. BPFE UGM. Yogyakarta.

Saleem, Faiza., Bisma Rafique, Qaiser Mehmood, Muhammad Irfan, Rabia Saleem, Sidra Tariq, dan Ghazala Akram. 2013. The Determinant of Capital Structure of Oil and Gas Firms Listed on Karachi Stock Exchange In Pakistan. Interdisciplinary Journal of Contemporary Reaserch In Business, 4 (9):225-235.

Santhi, I Gusti Ayu Padma dan Luh Komang Sudjarni. 2015. Pengaruh Corporate Governance, Rasio Pajak, Profitabilitas, dan Ukuran Perusahaan terhadap Struktur Modal. E-Jurnal Manajemen Universitas Udayana, 4 (3):678-692.

Sari, Resy Megadani Cahaya. 2015 Faktor - Faktor Yang Mempengaruhi Struktur Modal Perusahaan Manufaktur di Bei Tahun 2010 -2012. Thesis. Fakultas Ekonomi UNISSULA. 
Sarlija, Natasa., and Harc, Martina. 2012. The Impact of The Liquidity on The Capital Structure: a Case Study of Croation Firms. Business System Research, 3 (1):30-36.

Sartono, Agus R. 2014. Manajemen Keuangan Teori Dan Aplikasi. Edisi Empat.Yogyakarta: BPFE.

Setyawan, Arief Indra Wahyu, Topowijono dan Nila Firdausi Nuzula. 2016. Pengaruh Firm Size, Growth Opportunity, Profitability, Business Risk, Effective Tax Rate, Asset Tangibility, Firm Age dan Liquidity terhadap Struktur Modal Perusahaan (Studi pada Perusahaan Sektor Property dan Real Estate yang Terdaftar di BEI Tahun 2009-2014). Jurnal Administrasi Bisnis (JAB), 31 (1):108-117.

Shah, Attaullah and Tahir Hijazi.2004. The Determinants of Capital Structure of Stock Exchange listed Non Financial Firms in Pakistan, 43(4):605-618

Sheikh, Nadeem Ahmed., dan Zongjun, Wang. 2011. Determinant of Capital Structure An Empirical Study of Firms in Manufacturing Industri of Pakistan. Managerial Finance, 37 (2):117-133.

Shintayani, Dian dan Ida Bagus Panji Sedana. 2015. Determinan Struktur Modal (Studi Komparatif pada Manufactur Multinational Corporation dan Domestic Corporation di BEI). E-Jurnal Manajemen Universitas Udayana, 4(10):3375-3404.

Suweta, Ni Made Novione Purnama Dewi dan Made Rusmala Dewi. 2016. Pengaruh Pertumbuhan Penjualan, Struktur Aktiva, Dan Pertumbuhan Aktiva Terhadap Struktur Modal. E-Jurnal Manajemen Unud, 5 (8):51725199.

Ukaegbu, Ben dan Isaiah Oino. 2014. The determinants of capital structure A Comparison of Financial and Non-Financial Firms in A Regulated Developing Country-Nigeria. African Journal of Economic and Management Studies, 5 (3):341-368.

Utama, Made Suyana. 2014. Aplikasi Analisis Kuantitatif. Denpasar: Fakultas Ekonomi dan Bisnis.

Wiagustini, Ni Luh Putu. 2014. Dasar-dasar Manajemen Keuangan. Cetakan Pertama. Denpasar: Udayana University Press.

Widodo, Cahyo. 2013. Analisis Faktor-Faktor yang Mempengaruhi Struktur Modal Perusahaan Sektor Pertambangan yang Terdaftar di Bursa Efek Indonesia. Skripsi. Program Sarjana Alih Jenis Manajemen Fakultas Ekonomi dan Manajemen Institut Pertanian Bogor. 
Made Yunitri Deviani, Pengaruh Tingkat Pertumbuhan, Struktur Aktiva...

Yadav, Chette Srinivas. 2014. Determinants Of The Capital Structure And Financial Leverage: Evidence Of Selected Indian Companies. Asia Pacific Journal of Research, 1 (8):121-130. 